\title{
Aktualisasi Pancasila dalam Sepak Bola Indonesia
}

\author{
Andhika Djalu Sembada', Danang Prasetyo²
}

${ }^{1}$ Sekolah Tinggi Pariwisata Ambarrukmo Yogyakarta, andhikadjalu13@gmail.com
${ }^{2}$ Sekolah Tinggi Pariwisata Ambarrukmo Yogyakarta, danang.ppsuny@gmail.com

\section{INFO ARTIKEL}

Riwayat Artikel:

Diterima: 19 Juni 2020

Disetujui: 30 September 2020

Kata Kunci:

Aktualisasi Pancasila

Sepak Bola

\begin{abstract}
ABSTRAK
Abstrak: Aktualisasi Pancasila sebagai pandangan hidup dalam segala aspek kehidupan perlu untuk diwujudkan. Salah satu upaya mengaktualisasikan nilai nilai Pancasila dapat melalui bidang olah raga, dalam hal ini khususnya adalah sepak bola Indonesia. Tujuan yang penelitian ini ingin mengulas tentang aktualisasi Pancasila melalui olah raga sepak bola. Jenis penelitian ini adalah penelitian deskriptif dengan menggunakan pendekatan kualitatif. Penentuan subjek penelitian mengunakan teknik sampel bertujuan (purposive sampling) yakni pelatih dan pemain. Sebagai pelengkap hasil penelitian, sumber data yang digunakan berasal dari hasil penelitian yang relevan dan berita di media massa. Hasil penelitian ini menunjukan adanya aktualisasi Pancasila melalui aktivitas sepak bola di lapangan saat pertandingan maupun di luar lapangan. Aktivitas yang dilakukan oleh pelatih, pemain, dan perangkat pertandingan telah menunjukan pengalaman nyata nilai-nilai yang terkandung dalam sila-sila Pancasila. Melalui aktualisasi yang terdapat pada masing-masing sila Pancasila dapat memberikan sebuah pemahaman kembali mengenai arti pentingnya nilainilai pancasila itu sendiri. Sehingga sepak bola dapat dijadikan metode untuk pengembangan, pemahaman, dan pengamalan nilai-nilai Pancasila.
\end{abstract}

\begin{abstract}
The actualization of Pancasila as a view of life in all aspects of life needs to be realized. One of the efforts to actualize the values of Pancasila can be through the field of sports, in this particular case is Indonesian football. The purpose of this study is to review the actualization of Pancasila through soccer. This type of research is a descriptive study using a qualitative approach. Determination of research subjects using purposive sampling technique, namely coaches and players. As a complement to research results, the data sources used come from relevant research results and news in the mass media. The results of this study indicate the actualization of Pancasila through football activities on the field during matches and outside the field. Activities carried out by coaches, players, and match equipment have shown real experience of the values contained in the principles of Pancasila. Through the actualization contained in each Pancasila principle, it can provide a reunderstanding of the importance of the values of Pancasila itself. So that football can be used as a method for developing, understanding and practicing the values of Pancasila.
\end{abstract}

\section{A. LATAR BELAKANG}

Aktualisasi pancasila hingga masa yang sekarang ini, masih belum benar-benar dicermati dan dipahami oleh masyarakat. Hal ini dapat dilihat melalui semakin maraknya penyimpangan yang dilakukan sehingga melanggar nilai-nilai dari pancasila. Penyimpanganpenyimpangan yang dilakukan dilakukan oleh beberapa oknum karena kurang adanya rasa nasionalisme dalam dirinya, sehingga upaya dan proses mengaktualisasikan nilai-nilai Pancasila belum mampu dilaksanakan dengan baik dan benar. Sebagai sebuah bangsa yang bermartabat, harus dapat menentukan suatu kebijakan yang dianggap baik. Dalam kata lain, sudah sewajarnya dan sudah sepantasnya jangan sampai melanggar nilainilai yang terdapat pada Pancasila.

Pancasila sebagai sebuah dasar negara Indonesia yang sudah ada sejak zaman dahuluu, secara ideal digunakan sebagai pandangan hidup dan sudah seharusnya dijadikan pedoman bagi seluruh bangsa
Indonesia dalam kehidupan bernegara, berbangsa dan bermasyarakat. Terlebih lagi akan terasa sangat bagus apabila warga masyarakat mulai sadar dan memahami fungsi Pancasila serta melaksanakan dalam kehidupan sehari-hari.

Melakukan hal tersebut merupakan upaya mewujudkan Indonesia sebagai negara yang maju dan besar, sehingga diperlukan usaha yang keras dan rasa saling pengertian, hidup bertoleransi, saling menghargai keberadaan sesama, serta dengan memahami dan mengimplementasikan nilai-nilai Pancasila ke dalam kehidupan sehari-hari. Sudah seharusnya masyarakat Indonesia secara sadar berusaha mengetahui, memahami, dan mengimplementasikan nilai-nilai Pancasila dalam segala aspek kehidupan supaya cita-cita kemerdekaan dapat diwujudkan [1].

Salah satu upaya mengaktualisasikan nilai nilai Pancasila melalui bidang olah raga, dapat dilakukan melalui sepak bola. Selama ini, sepak bola bukanlah hal 
yang asing dalam kehidupan masyarakat. Olah raga ini masih menjadi paling favorit di Indonesia. Antusias masyarakat Indonesia sangat besar, terbukti dengan selalu penuhnya stadion saat klub lokal atau timnas (tim nasional) bertanding. Namun prestasi yang diraih belum maksimal, khususnya di level internasional sehingga menimbulkan banyak reaksi dan tanggapan dari berbagai elemen masyarakat. Beragam reaksi dan tanggapan tersebut bervariasi pada setiap orang, bagi para penikmat sepak bola misalnya, akan disuguhkan keanekaragaman sepak bola dari berbagai sudut pandang. Mulai dari sudut pandang supporter di lapangan, suporter layar kaca, haters, nitizen, keilmuan secara akademik, dunia kepelatihan, dan lain sebagainya. Namun bagi yang kurang atau bahkan tidak menyukai sepak bola, bukan berarti tidak dapat memberikan sumbangsih apapun bagi dunia sepak bola. Reaksi dan tanggapan dari mereka yang tidak meyukai sepak bola juga dapat dijadikan bahan evaluasi, dalam hal ini yang dimaksud adalah terkadang sudut pandang mereka tidak terpikirkan oleh penikmat sepak bola. Sudut pandang yang berbeda inilah yang idealnya dapat disatukan untuk memajukan sepak bola, khususnya sepak bola Indonesia. Hal tersebut sejalan dengan pasal 4 Undang Undang No 3 tahun 2005 tentang Sistem Keolahragaan Nasional Republik Indonesia menjelaskan bahwa tujuan keolahragaan nasional, yakni memelihara dan meningkatkan kesehatan dan kebugaran, prestasi, kualitas manusia, menanamkan nilai moral dan akhlak mulia, sportivitas, disiplin, mempererat, membina persatuan kesatuan bangsa, memperkukuh ketahanan nasional, serta mengangkat harkat, martabat dan kehormatan bangsa.

Induk organisasi olah raga sepak bola Indonesia dalam hal ini PSSI (Persatuan Sepak bola Seluruh Indonesia), tengah berupaya untuk memajukan kembali persepak bolaan Indonesia. PSSI melalui Direktur Teknik dan Tim High Performance Unit (HPU) bekerja sama dengan AFC (Asian Football Confederation) dan FIFA (Federation Internationale de Football Association) serta dengan beberapa federasi sepak bola yang lainnya seperti federasi sepak bola Jerman dan Australia berupaya secara maksimal untuk memajukan kualitas pelatih-pelatih Indonesia. Harapan yang ingin dicapai tentu saja demi sebuah prestasi sepak bola nasional di level internasional. Kemudian dengan terpilihnya Indonesia sebagai tuan rumah Piala Dunia Sepak bola U-20 tahun 2021, dapat menjadi salah satu jalan untuk meraih prestasi di level yang lebih tinggi.

Upaya untuk meraih prestasi tersebut perlu dilakukan dengan semangat gotong royong dan kebersamaan, hal ini disebabkan masih banyak aspekaspek detail yang perlu dibenahi. Sepak bola Indonesia yang dinikmati sekarang ini tentu saja tidak lepas dari pro dan kontra yang mengikutinya. Sekali lagi, sudut pandang yang berbeda tersebut idealnya dapat dijadikan sebagai acuan untuk merefleksikan kembali untuk menuju ke arah yang lebih baik. Kasus yang paling sering disaksikan atau dibaca di berita dalam beberapa tahun terkahir adalah masih banyak pemain yang belum dapat menerima keputusan wasit dan akhirnya melakukan hostille agression berupa sebuah pemukulan, dorongan, atau tindakan lain yang berupa kontak fisik kepada wasit, sehingga pemain tersebut mendapat kartu merah dan merugikan diri sendiri serta tim. Selain itu, berbagai situasi seperti perkelahian antar pemain, keputusan yang memihak, isu match fixing (suap), isu rasis, dan kerusuhan penonton pun masih sering terjadi.

Berdasarkan contoh permasalahan tersebut, dapat menjadi gambaran bahwa sebagia pelaku di sepak bola belum menerapkan nilai-nilai Pancasila dalam aktivitasnya. Apabila para pelaku sepak bola tersebut mampu untuk mengaktualisasikan Pancasila dalam sepak bola, maka secara individu tidak akan menyimpang, sikap fair play dan sportif akan jauh lebih terlihat. Oleh sebab itu maka Pancasila menjadi dasar utama bangsa Indonesia untuk mewujudkan persatuan dalam pemikiran dan gerakan membela NKRI (Negara Kesatuan Republik Indonesia) [2].

Penelitian ini bermaksud untuk mengupas aktualisasi Pancasila dalam aktivitas olah raga ini. Sudah ada beberapa penelitian sebelumnya yang relevan dengan kajian tentang nilai-nilai Pancasila dan kewarganegaraan dalam kegiatan olah raga. Seperti yang pernah dilakukan oleh Anirotul Qoriah yang terbit di jurnal Media Ilmu Keolah ragaan Indonesia dengan judul Nasionalisme Olah Raga [3] bahwa olah raga menjadi sarana untuk membangun nasionalisme bangsa sebagai motivasi para olah ragawan dan atlet. Maka penting memanfaatkan olah raga untuk membangun nasionalisme dan pula memanfaatkan nasionalisme untuk membangun olah raga di Indonesia.

Selain itu Aji R pernah mengulas tentang Sepak Bola dalam Olimpiade Masa Orde Lama (1945-1966) dalam Jurnal Mozaik Humaniora pada tahuun 2016 [4] bahwa olah raga, terutama sepak bola, merupakan ajang penting dalam memperkenalkan Indonesia dan membuktikan eksistensi bangsa baru secara global. Sepak bola adalah olah raga paling populer di dunia karena hampir setiap negara di dunia memainkan dan mengembangkan olah raga ini, sehingga keberhasilan dan prestasi dalam kompetisi sepak bola dunia akan membuat bangsa bangga dan pada saat yang sama meningkatkan citra negara di mata di dunia. Penelitian tersebut menemukan bahwa sepak bola dapat digunakan untuk membangkitkan semangat nasionalisme. Nasionalisme tidak hanya dalam bentuk perjuangan dengan mengangkat senjata, tetapi dapat ditampilkan melalui keterlibatan dalam olah raga. Meskipun negara Indonesia belum terbentuk, PSSI (Persatuan Sepak Bola Seluruh Indonesia) telah menegaskan 'ke-Indonesiaan' melalui sepak bola. 
Selain itu Maliki pernah menulis tentang manfaat kepemimpinan dalam olah raga yang mampu membangun karakter bangsa (Sebuah Perspektif Pembangunan Kewarganegaraan) pada tahun 2015 di Jurnal Ilmiah [5] bahwa olah raga dan aktivitas fisiknya mampu membangun karakter dan mengembangkan nilai-nilai moral. Melalui aktivitas olah raga banyak menghadirkan hal-hal yang positif, karena bukan sekedar kegiatan yang berorientasi kepada faktor fisik belaka, namun dapat melatih sikap dan mental kita menjadi seorang pemimpin. Pembentukan karakter bangsa dapat dilakukan salah satunya melalui olah raga. Dengan olah raga dapat menguatkan karakter bangsa, sportivitas sekaligus merekatkan persatuan bangsa. Atas dasar tersebut, semua komponen bangsa harus memberikan andil dalam memajukan olah raga nasional.

Kandungan nilai Pancasila dapat dibangun dan diaktualisasikan dalam berbagai aspek kehidupan, sehingga hal tersebut menjadi bagian yang utuh dalam menjalani kehidupan berbangsa dan bernegara, termasuk dalam olah raga sepak bola. Hal ini menjadi penting karena melalui sepak bola, banyak sekali nilainilai pancasila yang dapat diaktualisasikan. Penguatan aktualisasi nilai-nilai Pancasila mesti dilakukan secara intensif, demikian juga di bidang olah raga, dengan memiliki jiwa dan semangat patriotisme membela kebenaran. Hal tersebut akan dirasa lebih ideal apabila dalam berkegiatan olah raga atau ketika mengajarkan/melatih sepak bola juga diberikan pemahaman mengenai nilai-nilai aktualisasi Pancasila yang terkandung dalam masing-masing sila ke dalam aktivitas sepak bola.

Berdasarkan penjelasan di atas, tampak jelas bahwa nilai-nilai Pancasila sangat terikat dalam pertandingan olah raga, khususnya sepak bola. Hal ini disebabkan, Pancasila merupakan pedoman hidup dalam bermasyarakat, dan memiliki cakupan yang luas termasuk dalam lingkup olah raga sepak bola sekalipun. Tujuan yang ingin dicapai adalah untuk memberikan pemahaman akan sebuah nilai-nilai aktualisasi Pancasila bagi masyarakat, melalui sebuah kegiatan olah raga, sepak bola. Melalui aktualisasi nilai-nilai Pancasila dalam sepak bola Indonesia, segala macam permasalahan yang terdapat dalam sepak bola selama ini, dapat didiskusikan dan dikaji lebih dalam.

Tujuan dari penelitian ini adalah untuk mengetahui seberapa jauh nilai-nilai Pancasila dapat diaktualisasikan dalam aktivitas olah raga, khususnya sepak bola, baik di saat latihan, pertandingan, dan aktivitas di kehidupan sehari hari. Berbagai fenomena serta contoh kasus yang sering muncul terkait dengan sepak bola yang memiliki relevansi dengan nilai-nilai Pancasila dapat dijadikan sumber data. Penelitian ini diharapkan mampu melengkapi penelitian sebelumnya karena belum secara spesifik membahas pada olah raga sepak bola, sehingga mampu mengetahui sejauh mana aktualisasi nilai-nilai Pancasila terjadi dalam sepak bola Indonesia.

\section{B. METODE PENELITIAN}

Tulisan ini menggunakan metode penelitian kualitatif. Danzel \& Lincoln [6] yang menghasilkan data deskriptif berupa ucapan, tulisan dan perilaku orang-orang yang diamati [7] Penentuan subjek penelitian dilakukan secara purposive, yakni pelatih di Liga 1 Indonesia dan pemain sepak bola Tim Nasional Indonesia sekaligus pemain klub di Liga 1 Indonesia. Adapun subjek penelitian yang dipilih adalah pelatih sekaligus mantan pemain tim nasional Aji Santoso. Selain itu beberapa pemain tim nasional senior diantaranya Evan Dimas Darmono, Septian David Maulana, dan Awan Setho Raharjo. Adapun pemain tim nasional U-19 yang dipilih adalah Saddam Emiruddin Gafar.

Teknik pengumpulan data menggunakan wawancara sebagai sumber data primer yang mengacu pada daftar pertanyaan yang telah disiapkan. Selain itu data berasal dari dokumentasi hasil penelitian, artikel ilmiah, dan berita di media massa sebagai sumber sekunder. Pengumpulan data dilakukan dari bulan Mei sampai dengan bulan Agustus tahun 2020.

Adapun analisis data dengan tahapan sebagai berikut. Pertama, reduksi data dengan merangkum dan memilih data-data yang sesuai dengan fokus tujuan penelitian. Kedua, penyajian data untuk memahami arah tujuan penelitian. Ketiga, verifikasi atau penarikan kesimpulan. Creswell [8] menyatakan bahwa informasi yang didapat berupa kata atau teks kemudian dianalisis berupa deskripsi.

\section{HASIL DAN PEMBAHASAN}

Sepak bola yang berpedoman pada Pancasila dapat direfleksikan menjadi suatu aturan, permainan, pertandingan yang didasarkan pada nilai-nilai sportifitas dan fair play. Hal ini dapat diartikan sebagai suatu sikap kesiapan dan kesediaan untuk mentaati peraturan, termasuk menghormati wasit dan lawan, sedangkan sportif dapat diartikan sebagai sebuah etika atau nilai moral untuk mentaati peraturan tanpa paksaan dari luar (kesadaran diri sendiri). Apabila unsur fair play dan sportivitas sedikit saja terabaikan, maka dapat mempengaruhi esensi dari sebuah pertandingan sepak bola. Faktor-faktor yang dapat mempengaruhi fair play dan sportivitas dalam sepak bola antara lain, sentimen kedaerahan, prestise, serta keuntungan finansial sebagai target pragmatis. Menurut Rusli Luthan [9] fair play merupakan kebesaran hati dan empati terhadap lawan sehingga menimbulkan hubungan kemanusiaan yang akrab, hangat dan bersahabat. Sikap ini merupakan perwujudan mentalitas yang menunjukan martabat manusia yang ksatria pada bidang olah raga. Fair play juga dapat diartikan sebagai sikap kerendahan hati dalam kemenangan dan ketenangan diri untuk tidak sombong saat mendapatkan kemenangan, serta 
pengendalian diri dalam menerima kekalahan tanpa putus asa.

Sportivitas mampu menjadi etika inheren dalam olah raga [10], bukan hanya terpaku pada berbagai kebijakan-kebijakan moral seperti kejujuran, kesatriaan, tanggung jawab serta kedamain, melainkan mampu mengaplikasikan dari semuanya itu untuk dapat diterapkan pada pertandingan olah raga. Cara yang dapat dilakukan dengan menganggap lawan bertanding sebagi kawan bertanding, sehingga dapat terbangun permainan yang baik. Segala bentuk sikap sportivitas bertumpu pada penghargaan kepada semua peserta yang terlibat pada permainan, dengan itu akan tercipta permainan yang fair play. Sikap ini menuntut semua peserta memiliki kesempatan yang sama untuk mengejar kemenangan dalam olah raga kompetitif, serta memiliki kemampuan meraih kemenangan melalui sikap yang elegan, sportif dan adil [11] fair play juga dapat dimaknai bahwa semua kontestan tidak hanya memahami dan mematuhi terhadap sebuah aturan formal dari permainan tetapi juga peraturan permainan yang tidak tertulis. Sama seperti pendapat Amansyah, [11] bahwa fair play merupakan sikap mental yang menunjukkan martabat ksatria pada olah raga yang mampu melandasi pembentukan sikap, dan selanjutnya sikap menjadi landasan perilaku.

Jiwa sportivitas dan fair play jelas menjadi bukti nyata aktualisasi Pancasila. Aktualisasi nilai-nilai Pancasila dalam pertandingan sepak bola harus tercermin pada perilaku para pelaku sepak bola Indonesia. Para pelaku sepak bola harus dapat mengendalikan perilaku supaya tidak mudah terprovokasi, tidak mudah mengeluarkan kata-kata rasis, saling ejekan, dan tidak berperilaku menyimpang. Kemenangan dalam sebuah pertandingan dapat dijadikan modal motivasi untuk lebih berprestasi lagi. Saat mengalami kekalahan tidak larut dalam kesedihan, kekecewaan, kepedihan, dan keputusasaan. Kekalahan justru menjadi pembelajaran untuk bangkit kembali dan berusaha supaya lebih baik dengan cara-cara yang sehat, inilah etika Pancasila dalam sudut pandang aktivitas olah raga sepak bola.

Selain itu penonton dan pendukung diharapkan untuk tidak terlibat tawuran, tidak mengamuk, dan berbuat anarkis apabila tim kesayangannya kalah. Menerima kekalahan sebagai suatu kenyataan karena dalam setiap pertandingan, pasti ada tim yang menang dan harus ada tim yang kalah. Fanatisme yang berlebihan dan dukungan penuh yang diberikan idealnya tidak perlu merendahkan tim lain, apalagi mengeluarkan kata-kata rasis, dan melecehkan dengan cara apapun, karena itu tidak sesuai dengan nilai-nilai etika pancasila.

Beberapa waktu yang lalu muncul isu bahwa terjadi skandal pengaturan skor pertandingan sepak bola yang melibatkan banyak sekali oknum. Bahkan diduga ada oknum petinggi federasi yang terlibat dalam skandal tersebut dimana seharusnya federasi bertugas mengatur jalannya kompetisi dengan netral guna memajukan persepakbolaan Indonesia. Hal tersebut telah dibahas dalam salah satu acara di salah satu stasiun televisi swasta nasional pada 28 November 2018. Kejadian ini tentu saja mencoreng citra Indonesia di mata dunia dan tentu saja melanggar nilai-nilai yang terkandung dalam Pancasila. Hal-hal semacam itu sudah sepatutnya diperangi, dibasmi dengan peran serta dari pemerintah, petinggi-petinggi federasi, pemain-pemain, jajaran manajemen, serta masyarakat harus mampu bersinergi guna membasmi praktik pengaturan skor semacam ini supaya persepakbolaan di Indonesia menjadi bersih sesuai dengan pandangan hidup berbangsa dan bernegara.

Pancasila yang merupakan dasar negara, ideologi bangsa, falsafah serta pandangan hidup bangsa, yang di dalamnya terkandung nilai dasar, nilai instrumental dan nilai praksis. Selain itu Pancasila juga dapat dimaknai sebagai sebuah ideologi terbuka yang setidaknya memiliki dua dimensi nilai-nilai, yaitu nilai-nilai ideal dan nilai-nilai aktual. Akan tetapi, nilai-nilai tersebut kondisinya dipengaruhi pula oleh nilai-nilai yang dibawa melalui globalisasi, sehingga berdampak terjadinya pergeseran peradaban, yang juga membawa serta perubahan pemaknaan dan posisi Pancasila [12].

Banyak yang tidak menyadari bahwa sepak bola Indonesia sesungguhnya merupakan aktualisasi langsung dari sila ketiga Pancasila yaitu, Persatuan Indonesia. Pada tahun 1930 di Yogyakarta, dibentuklah organisasi Persatuan Sepak Raga Seluruh Indonesia (PSSI) dan Ir. Soeratin terpilih menjadi Ketua Umum PSSI yang pertama. Dalam hal ini yang ingin ditekankan adalah bahwa dalam perumusan nama PSSI itu sendiri, sudah muncul rumusan dasar negara Pancasila yaitu, "Persatuan Indonesia". Apabila meneliti dan menganalisis saat-saat sebelum, selama, dan sesudah kelahirannya, sampai 5 tahun pasca Proklamasi Kemerdekaan 17 Agustus 1945, jelas sekali bahwa PSSI lahir, karena ada campur tangan politisi bangsa, baik secara langsung maupun tidak. Kemudian menentang penjajahan dengan strategi menanamkan benih-benih nasionalisme di jiwa pemuda-pemuda Indonesia.

Wujud nyata dari persatuan Indonesia pada masa awal-awal pembentukan PSSI terjadi pada tanggal 19 April 1930. Saat itu terdapat pertemuan yang dihadiri oleh wakil-wakil dari berbagai daerah. Perwakilanperwakilan yang pada saat itu hadir dalam pertemuan tersebut antara lain, VIJ (Sjamsoedin yang merupakan mahasiswa RHS), wakil dari Bandoengsche Indonesische Voetbal Bond (BIVB) Gatot, wakil dari Persatuan Sepak bola Mataram (PSM) Yogyakarta, Daslam Hadiwasito, A. Hamid, M. Amir Notopratomo, Soekarno yang mewakili Vortenlandsche Voetbal Bond (VVB) Solo, Kartodarmoedjo wakil dari Madioensche Voetbal Bond (MVB), E.A Mangindaan wakil dari 
Indonesische Voetbal Bond Magelang (IVBM) yang pada saat itu masih menjadi siswa HKS/Sekolah Guru, juga Kapten Kes. IVBM, kemudian wakil dari Soerabajashe Indonesische Voetbal Bond (SIVB), Pamoedji. Dari pertemuan tersebut lahirlah induk organisasi sepak bola Indonesia yang bernama PSSI (Persatoean Sepakraga Seloeroeh Indonesia), kemudian kepanjangan dari singkatan PSSI ini diubah dalam kongres PSSI di Solo 1950 menjadi Persatuan Sepak bola Seluruh Indonesia yang juga menetapkan Ir. Soeratin sebagai Ketua Umum PSSI.

Penjelasan di atas memberikan gambaran bahwa nilai-nilai yang terkandung di dalam sila Persatuan Indonesia sangat identik dengan nasionalisme. Begitu pula dengan sepak bola yang dapat dijadikan pembangkit nasionalisme yang paling mudah untuk dimunculkan. Tanpa memerlukan perang, rasa memiliki bangsa akan muncul dengan sendirinya. Sepak bola telah memberikan tempat bagi lahirnya kebanggaan terhadap sebuah negara. Primordialisme kedaerahan seakan hilang ketika tim nasional sepak bola Indonesia sudah atau sedang berlaga.

Sebagai contoh, pada tahun 2016 ketika timnas Indonesia baru saja terlepas dari suspend berat yang diberikan oleh FIFA akibat dualisme yang terjadi PSSI. Timnas akhirnya bisa tampil kembali ke pentas internasional dan ribuan suporter berbondong-bondong terlihat memadati stadion, antusiasiasme yang besar dan semangat yang membara terlihat saat menyanyikan lagu kebangsaan Indonesia Raya. Meski pada saat itu skor kemenangan telah dipastikan dikunci oleh timnas Indonesia, namun yang menjadi catatan besar adalah sepak bola telah memunculkan kembali rasa persatuan dan nasionalisme rakyat Indonesia.

Melalui penjelasan di atas, kita telah mengetahui bagaimana sepak bola Indonesia berproses. Begitu pun dengan dasar negara Indonesia yaitu Pancasila yang tidak lahir secara mendadak, melainkan melalui sebuah proses yang panjang dengan didasari oleh sejarah perjuangan bangsa dan tentu saja dengan melihat pengalaman perjuangan bangsa lain di dunia. Pancasila diilhami oleh gagasan-gagasan besar dunia, tetapi tetap berakar pada kepribadian dan gagasan besar bangsa Indonesia sendiri. Pancasila berfungsi sebagai pedoman kehidupan dalam masyarakat Indonesia dan telah ditetapkan sebagai dasar negara. Artinya, Pancasila merupakan satu kesatuan sebagai nilai kehidupan masyarakat segala aspek kehidupan dan merupakan dasar negara Indonesia.

Selanjutnya, dalam proses perumusan Pancasila, Ir. Soekarno mensintesiskan berbagai pandangan yang telah muncul dan mengkonseptualisasikan dasar negara ke dalam pengertian dasar falsafah (philosofische grondslag), atau pandangan komperehensif dunia (weltanschauung) secara sistematik dan koheren [12]. Berdasarkan pada hal tersebut di atas, dapat disimpulkan bahwa Pancasila merupakan suatu perjanjian luhur yang harus dijadikan pedoman bagi bangsa, pemerintah, dan seluruh rakyat Indonesia.

Paparan tentang terbentuknya PSSI sebagai bukti aktualisasi Pancasila khususnya sila ketiga pada masa itu jelas menjadi bukti yang paling sederhana. Namun, penelitia akan mengulas lebih dalam tentang aktualisasi sila-sila lainnya. Adapun masing-masing sila dalam Pancasila secara detail dapat diaktualisasikan dalam aktivitas sepak bola sebagai berikut ini.

\section{Aktualisasi Sila Ketuhanan yang Maha Esa}

Secara prinsip, sila pertama menegaskan bahwa bangsa Indonesia dan setiap warga negara harus mengakui adanya Tuhan. Segenap agama dan aliran kepercayaan diakui oleh negara, mendapat tempat dan perlakuan yang sama oleh negara. Atas dasar hal tersebut, setiap warga negara Indonesia dianjurkan untuk menjunjung tinggi nilai-nilai ketuhanan menurut agama dan kepercayaannya masing-masing.

Aktualisasi dari sila pertama dalam sepak bola dapat dijumpai dari perilaku para pelaku sepak bola yang terlibat di dalamnya, seperti pemain, pelatih, menejemen, wasit perangkat pertandingan, dan lain-lain saat sebelum, selama, dan sesudah pertandingan, yaitu berdoa. Seperti halnya yang disampaikan oleh Awan Setho Raharjo (wawancara tanggal 15 Agustus 2020) bahwa ungkapan syukur menjadi wajib, apapun hasil pertandingannya baik menang maupun kalah. Berdoa menjadi pondasi utama memulai setiap perjuangan dan harus diperjuangkan dengan sekuat daya upaya di atas lapangan sepak bola.

Seperti yang telah disampaikan sebelumya bahwa tiap-tiap pemeluk agama memiliki cara berdoa sendirisendiri. Hal yang harus ditekankan bahwa perbedaan bukanlah penghalang. Justru dengan berdoa kepada Tuhan diharapkan akan muncul perasaan tenang, motivasi yang positif, serta fair play dan sportifitas bisa terwujud. Seperti halnya selebrasi pemain Bali United, berdoa mengucapkan syukur sesuai dengan agamanya masing-masing untuk mengucapkan rasa syukur (Hindu, Nasrani, Muslim) seperti gambar di bawah ini.

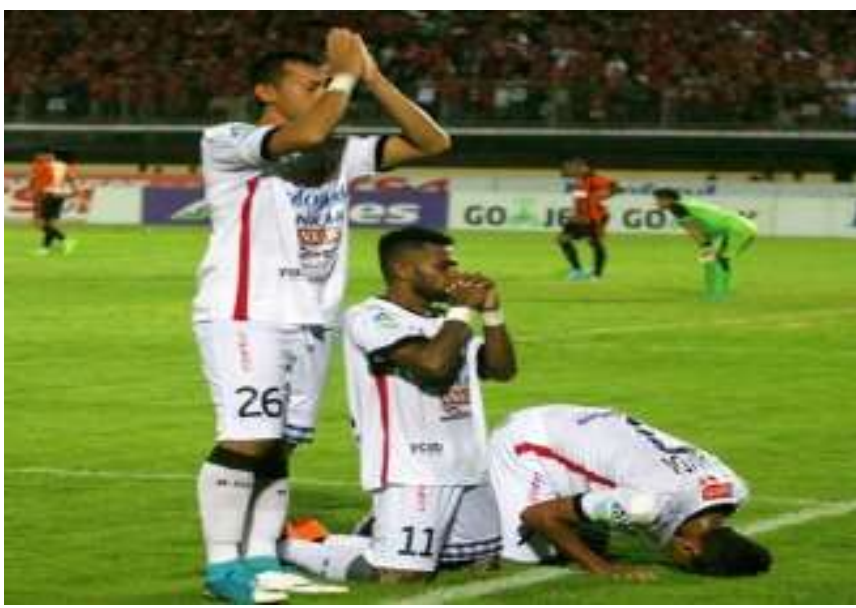

Gambar 1. Selebrasi Syukur Pemain Bali United [13]. 
Selain unggkapan rasa syukur, para pemain sepak bola telah membiasakan untuk hidup dengan semanta toleransi antar umat beragama. Rasa saling menghargai antar pemeluk agama menjadi hal yang sangat lumrah terjadi dalam aktivitas para pemainnya. Sebagaimana tergambar jelas dalam foto selanjutnya. Ketika para pemain yang Muslim sedang salat berjamaah di dalam ruang ganti stadion sepak bola, maka para pemain yang beraga lain akan memberikan kesempatan dan menjaga ketenangannya. Seperti pada foto di bawah ini, dimana nampak di pojok ruangan Boaz Sollosa dan Stefano Lilipaly yang beragama lain turut berpartisipasi supaya pelaksanaan ibadah rekan-rekannya dapat berjalan dengan baik dengan cara menjaga supaya tidak ada orang dari luar sembarangan masuk ke dalam ruang ganti sebagaimana tercermin dari gambar di bawah ini.

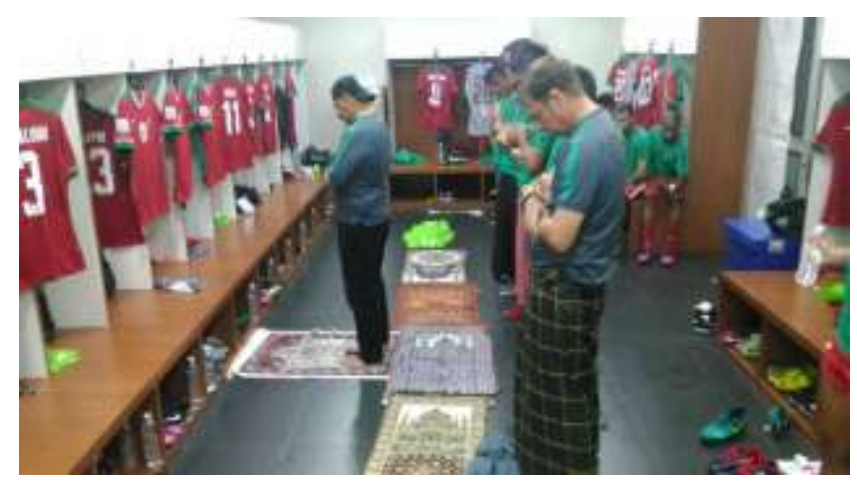

Gambar 2. Ibadah Salat di Ruang Ganti Pemain [14].

\section{Aktualisasi Sila Kemanusiaan yang Adil dan Beradab}

Sila kedua secara prinsip menegaskan bahwa mengandung nilai moral kemanusiaan. Seseorang dapat dikatakan memegang teguh nilai kemanusiaan jika setiap tindakan, perbuatannya selalu menjunjung seta menjaga harkat dan martabat orang lain. Perilaku yang adil terhadap sesama manusia juga merupakan wujud nyata dari adanya sifat kemanusiaan yang dimiliki oleh seseorang. Seseorang yang berpedoman pada sila kedua ini akan selalu memiliki rasa saling menghormati dan menghargai antar sesama manusia.

Aktualisasi dari sila kedua dalam sepak bola adalah pengendalian diri dalam sebuah situasi yang kurang menguntungkan. Sebagai contoh adalah ketika merasa dirugikan saat bertanding, sehingga menyebabkan munculnya sikap hostille agression yakni tindakan agresif yang disertai permusuhan dan dilakukan secara sengaja dengan perasaan marah dan dengan maksud untuk melukai/mencederai dan menyakiti lawan bertanding. Fenomena ini terkadang masih terjadi dalam setiap pertandingan. Kekecewaan pemain terhadap kinerja wasit yang dirasa buruk yang menjadi penyebabnya. Bahkan tidak hanya pemain saja yang melakukan tindakan hostille agression, terkadang staf pelatih juga terpancing untuk melakukan hal yang serupa. Apabila mampu mnegendalikan diri, maka kejadian tersebut tidak akan terjadi.

Sikap yang sesuai dengan sila kedua adalah ketika wasit yang berusaha untuk melerai perkelahian antar pemain, menennagkan emosi, dan memberi arahan terbaiknya. Sikap yang ditunjukan oleh wasit tersebut sangat patut untuk dicontoh. Jika seseorang dapat mengontrol situasi tersebut dengan baik, maka secara tidak langsung telah mengimplementasikan sila kedua.

Aktualisasi lainnya ditunjukan oleh rasa simpati terhadap sesama pemain, meskipun terdapat persaingan untuk mendapatkan posisi pemain inti tidak akan menimbulkan rasa benci antar pemain. Para pemain yang masuk ke dalan tim inti tidak lantas menganggap pemain cadangan sebagai ancaman, begitu juga pemain cadangan tidak akan merasa disingkirkan dengan keberadaan pemain yang masuk ke dalam tim inti. Para pemain pun harus bersiap secara mental untuk menghadapi cacian apabila tidak mendapatkan kemenangan. Seperti yang disampaikan Septian David Maulana (wawancara tanggal 15 Agustus 2020) bahwa cacian yang diterima tidak lantas dibalas dan menyurutkan semangat juangnya membela tim nasional, justru akan menjadi cambuk penyemangat meningkatkan kualitas permainan demi tim nasional.

Solidaritas di luar sepak bola juga dapat dijadikan contoh aktualisasi sila ini. Berbagi secara material, support moral kepada sesama masyarakat yang membutuhkan merupakan sebuah sikap yang menjunjung tinggi nilai-nilai kemanusiaan. Seperti yang dilakukan komunitas suporter penggemar Persebaya Surabaya yang memiliki nama Bonek Sukodono Jemundo 27 (Bonek SKJ27), dalam hal ini turut serta ambil bagian dalam upaya untuk berbagi keceriaan dan kebahagiaan bagi sesama. Hal tersebut dilakukannya dengan mendirikan Panti Asuhan Bonek, yang bertujuan supaya anak-anak yatim piatu dapat hidup layak dan dapat menggapai mimpinya. Melalui panti asuhan ini, banyak sekali masyarakat yang tergugah untuk membantu dengan berbagai macam cara. Melalui donasi, menyumbang pakaian, memberikan buku-buku pelajaran, dan lain sebagainya. Melihat aksi sosial yang dilakukan oleh Bonek SKJ27, secara langsung telah mewujudkan pengamalan dari sila kedua. 


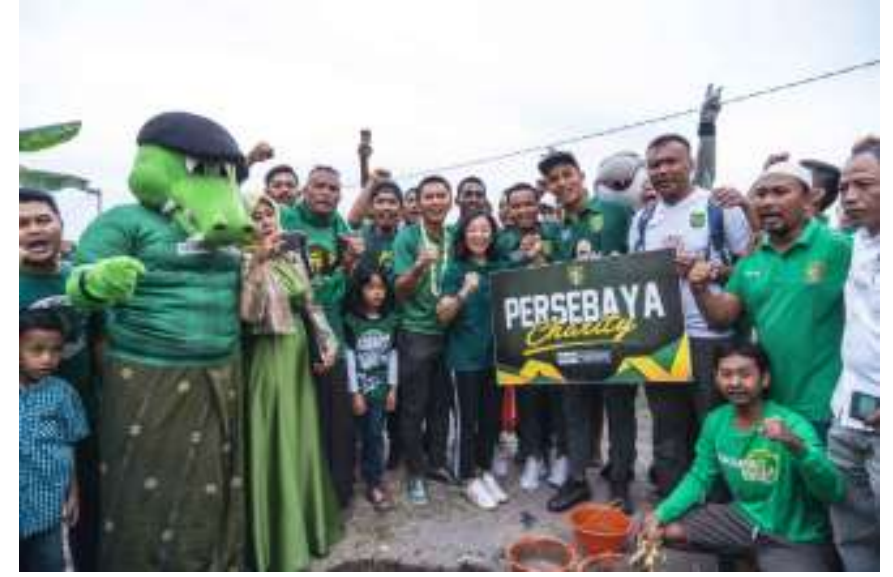

Gambar 3. Penggalangan Dana Supporter Persebaya [15]

Berhentinya kompetisi sepak bola di tanah air akibat dari pandemi covid-19, menyebabkan seluruh aktivitas sepak bola di Indonesia terhenti untuk sementara. Konsentrasi dan fokus untuk saat ini ditujukan supaya pandemi covid-19 segera berakhir. Berbagai hambatan yang muncul beragam macamnya, mulai dari masih banyak warga yang kurang kesadarannya akan protokol kesehatan yang telah diinfokan oleh pemerintah hingga keterbatasan perlengkapan medis. Fenomena tersebut memicu banyak pihak untuk turut serta berpartisipasi aktif sebagai bentuk rasa kemanusiaan. Salah satunya dilakukan oleh Asosiasi Pelatih Sepak bola Seluruh Indonesia (APSSI) yang melakukan aksi lelang jersey/apparel pelatih maupun pemain yang tergabung dalam naungan PSSI. Hasil dari lelang tersebut sepenuhnya diberikan kepada pihak-pihak yang terdampak covid-19 secara langsung. Adapun iklan lelang seperti gambar di bawah ini.

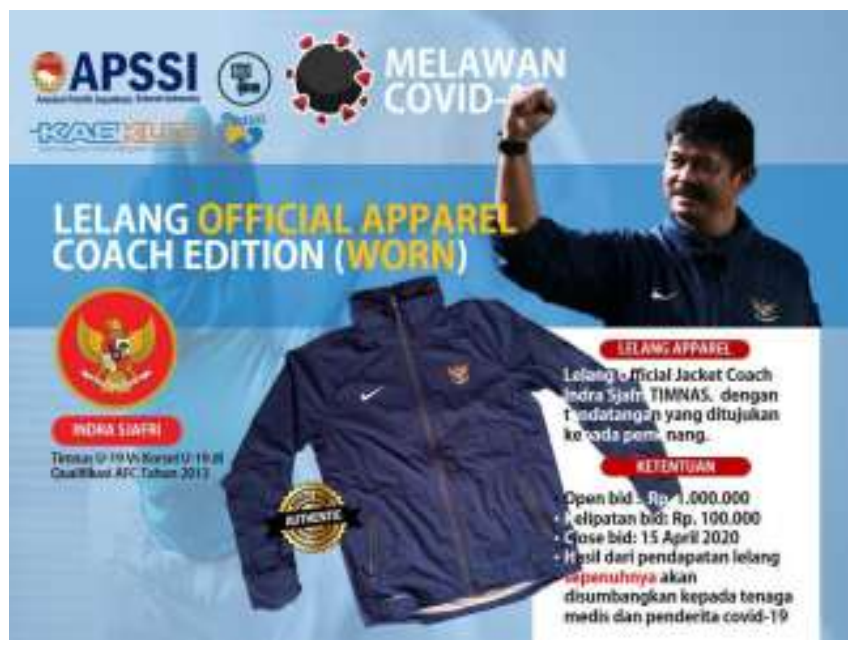

Gambar 4. Lelang Jersey untuk Donasi Amal [16].

\section{Aktualisasi Sila Persatuan Indonesia}

Secara prinsip, sila ketiga mengandung nilai moral persatuan bangsa dan mempertegas bahwa bangsa Indonesia merupakan negara kesatuan. Artinya adalah bahwa setiap warga negara Indonesia dimanapun berada akan bertindak tanpa ada niat sedikitpun untuk memecah belah bangsa. Secara tersirat, melalui sila ketiga ini juga menuntut pengakuan terhadap adanya perbedaan dan keaneka ragaman suku, bahasa, adat, agama dan budaya menjadi satu kesatuan sebagai pemersatu bangsa.

Pada hakekatnya sifat dan keadaan bangsa dan negara Indonesia adalah 'satu' yaitu dapat diartikan mutlak dan tidak dapat terbagi oleh apapun. Meskipun keberagaman yang di dalamnya banyak terdapat unsur perbedaan bukanlah menjadi penghalang bangsa Indonesia untuk terus memperkuat rasa yang satu yaitu semangat persatuan Indonesia atau sering disebut jiwa nasionalisme [17]. Semangat ini membutuhkan pengorbanan jiwa raga bagi pari pemain tim nasional. Seperti yang disampaikan Saddam Emiruddin Gafar (wawancara tanggal 15 Agustus 2020) bahwa pemain harus mengorbankan untuk meninggalkan waktu bermain di usianya dan keluarga di kampung halamanyya demi mengabdi kepada negara. Hal serupa disampaikan oleh Evan Dimas Darmono (wawancara tanggal 15 Agustus 2020) bahwa menjadi bagian tim nasional merupakan kesempatan untuk bela negara melalui olah raga sepak bola. Menurut Septian David Maulana (wawancara tanggal 15 Agustus 2020) apapun yang dilakukan pemain demi kejayaan tim nasional dan sepak bola nasional.

Bukti aktualisasi dari sila ketiga paling nyata dan dapat dilihat dengan adanya Tim Nasional Indonesia (Timnas). Melalui tim nasional sepak bola Indonesia, semua pemain terbaik dari seluruh penjuru tanah air akan berkumpul jadi satu untuk membela negara dan mengharumkan nama bangsa dalam kancah internasional. Hal ini dilakukan semata-mata demi bangsa dan negara, tanpa memandang asal usul daerah, warna kulit, suku dan serta agama. Semua itu tentu saja dilakukan dengan penuh kesadaran, tanggung jawab, dan rasa cinta terhadap bangsa dan negara Indonesia. Semua kelompok usia pada tim nasional sepak bola Indonesia dari U-15 hingga Tim Senior, selalu dihiasi oleh pemain yang berasal dari berbagai daerah di Indonesia. Ini menjadi bukti menjaga semangat persatuan dalam pluralitas multikultur kehidupan. Anggapan bahwa tim nasional sepak bola Indonesia hanya untuk pemain dari Jawa saja, sangatlah tidak pantas dan tidak ideal untuk diucapkan. Seperti keragaman pemain yang ada di gambar berikut ini. 


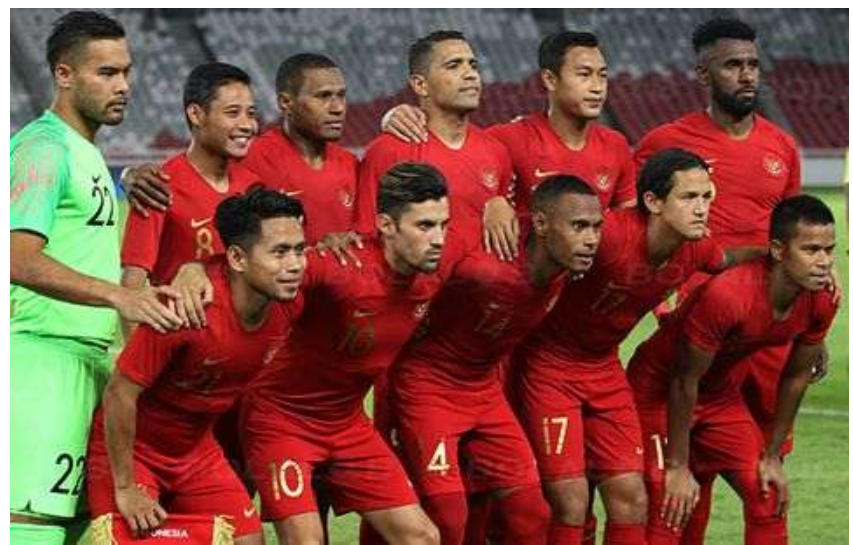

Gambar 5. Pemain Tim Nasional [18].

Berikut adalah daftar nama para pemain dalam foto di atas, posisi berdiri dari kiri ke kanan; Andritany (Jakarta), Evan dimas (Surabaya), Yustinus Pae (Jayapura), Beto (naturalisasi dari Brazil), Hansamu Yama (Mojokerto), Yanto Basna (Sorong) lalu posisi jongkok dari kiri ke kanan adalah Andik Vermansyah (Jember), Lilipaly (naturalisasi dari Belanda), Ruben Sanadi (Biak), Irfan Bachdim (naturalisasi dari Belanda), Manahati Lestusen (Maluku). Pemain terbaik dari beberapa tim yang ada di Indonesia berkumpul menjadi satu, membela merah putih dengan penuh kebanggaan terhadap lambang garuda di dada. Tidak ada alasan lain selain rasa cinta tanah air yang diutamakan. Tanpa memandang asal usul daerah asal, mereka semua bersatu menjadi satu kesatuan yang kuat dalam sebuah tim nasional sepak bola Indonesia.

Selain melalui tim nasional sepak bola, upaya yang mencerminkan pengamalan dari sila ketiga adalah dengan adanya kongres PSSI yang dihadiri oleh seluruh perwakilan klub dan asosiasi dari 34 provinsi yang ada di Indonesia. Seluruh perwakilan dari masing-masing provinsi dan pengurus klub tersebut berkumpul menjadi satu. Adapun agenda yang dilaksanakan salah satu diantaranya adalah menyuarakan aspirasi dari masingmasing perwakilan untuk kemajuan sepak bola bangsa Indonesia. Adapun bukti konggres tersebut disajikan dalam gambar berikut ini.

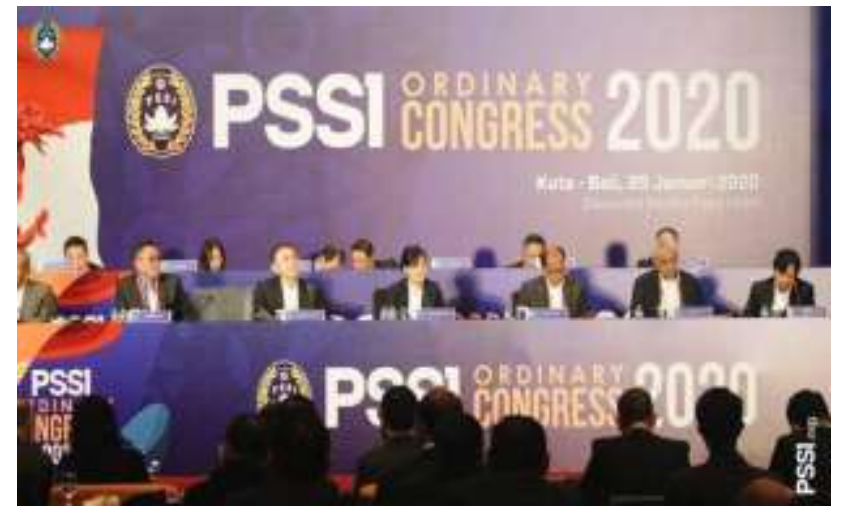

Gambar 6. Konggres PSSI tahun 2020 [19].

\section{Aktualisasi Sila Kerakyatan yang Dipimpin oleh Hikmat Kebijaksanaan dalam Permusyawaratan Perwakilan.}

Makna yang ingin disampaikan melalui sila keempat adalah, secara substansi sila keempat mengandung nilai moral kerakyatan atau musyawarah, dan demokrasi untuk berpendapat sehingga mendapatkan hasil musyawarah terbaik. Segala hal yang terjadi idealnya dapat diselenggarakan dengan musyawarah mufakat serta secara demokratis. Seseorang dapat dikatakan bisa mengaktualisasikan sila keempat apabila dapat saling menghargai, memegang teguh prinsip demokrasi, mengutamakan nilai kerakyatan dan menjunjung tinggi kebijaksanaan.

Aktualisasi sila keempat dalam sepak bola terdapat dalam diri kapten tim dan pelatih dalam tim tersebut. Seorang kapten tim harus memiliki sikap yang bijak serta dapat menjadi pemimpin yang baik di dalam maupun di luar lapangan, dan seorang pelatih tentu tidak sembarangan dalam memilih kapten. Proses pemilihan kapten dalam tim juga dilakukan dengan musyawarah mufakat dengan staf pelatih yang lain, yang pada prosesnya bersumber dari berbagai macam pertimbangan seperti, leadership, pandai berkomunikasi, mampu mengatur emosi, good football quality, dan lain sebagainya. Sosok tersebut tercermin dari diri Hansamu Yama Pranata, yang menjabat ban Kapten Tim Nasional Sepak Bola Indonesia saat ini.

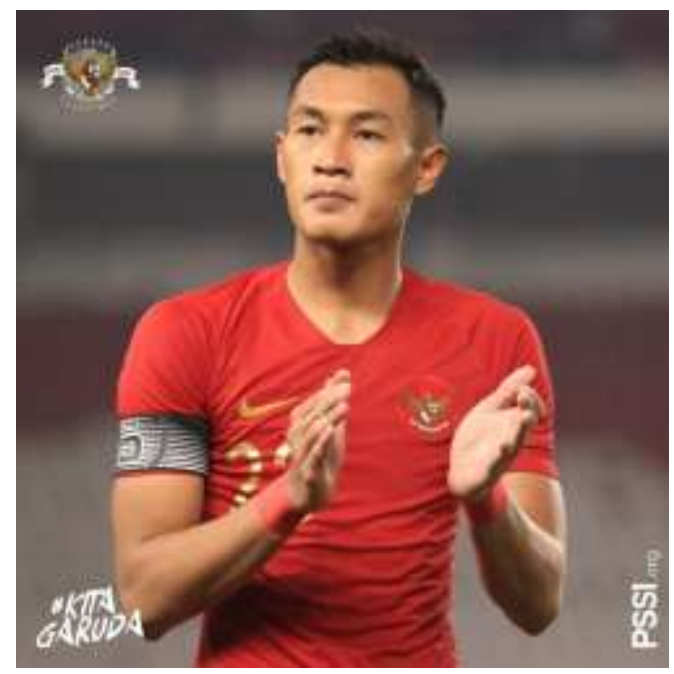

Gambar 7. Hansamu Yama Pranata, Kapten Tim Nasional [20].

Hal lain yang dapat dilakukan sebagai perwujudan dari sila keempat adalah adanya musyawarah mufakat. Sebelum kompetisi sepak bola Indonesia dimulai, PSSI selaku federasi selalu berkoordinasi dengan Polri, TNI, KONI, dan instansi terkait lainnya. Agenda yang dilakukan dalam koordinasi tersebut tentu saja bermusyawarah supaya pelaksanaan kompetisi dapat berjalan dengan baik dan lancar. Koordinasi dengan beberapa instansi menjadi sebuah agenda yang penting 
karena terkait dengan penjadwalan kompetisi dengan beberapa agenda lainnya seperti pemilihan umum (pilkada, pileg dan pilpres). Harapannya agenda-agenda tersebut dapat berjalan dengan lancar, maka musyawarah mufakat menjadi hal yang sangat penting untuk dilakukan.

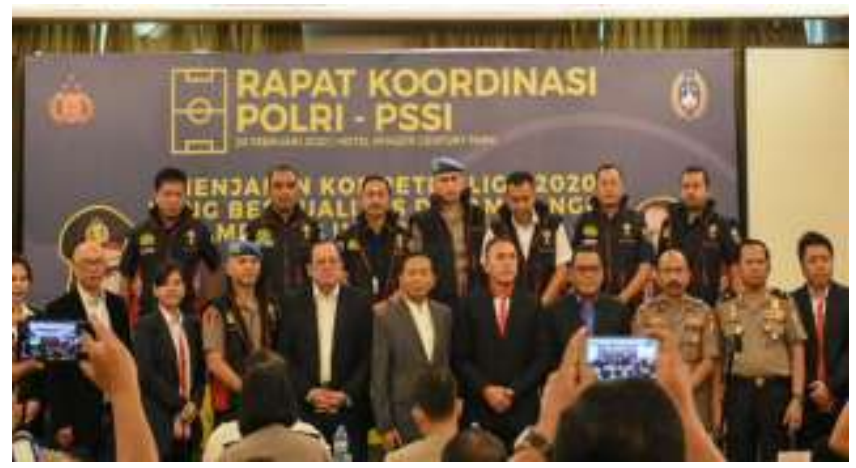

Gambar 8. Rapat Koordinasi Polri dan PSSI [21].

Contoh lain aktualisasi semangat musyawarah musyawarah juga ditunjukkan oleh keluarga besar para pemain tim nasional. Sebagaimana diungkapkan Saddam Emiruddin Gafar (wawancara tanggal 15 Agustus 2020) bahwa pemain harus mengorbankan waktu bersama keluarga di kampung halamanya demi membela tim nasional yang terlebih dahulu dimusyawarahkan dengan keluarga besarnya. Respon positif dan dukungan selalu diberikan keluarganya. Menurut paparan Evan Dimas Darmono (wawancara tanggal 15 Agustus 2020) aktivitasnya di tim nasional telah mendapat persetujuan dari keluarga besarnya sehingga harus meninggalkan waktu bersama keluarga untuk bergabung di training camp (pemusatan lahitan) untuk tetap fokus pada sepak bola hingga berakhirnya kompetisi.

\section{Aktualisasi Sila Keadilan Sosial bagi Seluruh Rakyat Indonesia}

Sila kelima pada dasarnya memilki wujud rasa dan sikap adil yang mencakup seluruh aspek kehidupan. Seseorang dapat dikatakan memiliki sikap adil apabila mampu bersikap adil untuk diri sendiri dan orang lain. Salah satu contoh dari aktualisasi sila kelima terdapat pada sosok pelatih. Seorang pelatih harus mampu bersikap adil terhadap dirinya, staf pelatih yang lain, serta kepada para pemain. Sebagaimana yang disampaikan Coach Aji Santoso (wawancara tanggal 27 Mei 2020) bahwa pelatih diharapkan mampu mengontrol dan membagi sikap secara adil dan tidak ada unsur-unsur tertentu yang dapat menyebabkan hilangnya kepercayaan terhadap seorang pelatih.

Adapun contoh sikap adil yang dimaksud adalah ketika mementukan pemain inti dan pemain cadangan. Penilaian yang diambil dalam menentukan kerangka tim tidak hanya dengan sekedar like and dislike, namun harus berdasarkan kualitas permainan. Proses selama latihan dan hasil analisis selama pertandingan menjadi faktor penting dalam menentukan kerangka sebuah tim. Meskipun keputusan ada di pelatih kepala, namun staf pelatih yang lain idealnya juga diberi kesempatan untuk memberikan pendapat, sehingga staf pelatih yang lain juga mendapat perlakuan yang adil. Kemudian seorang pelatih idealnya dapat memberikan jam terbang yang cukup kepada pemain muda (junior). Seorang pemain muda juga harus dapat merasakan kesempatan yang sama. Hal ini akan berkaitan dengan perkembangan bagi pemain muda itu sendiri di masa yang akan datang. Meskipun masih ada stigma bahwa perihal adil dalam sepak bola menjadi hal yang dilematis, karena pada faktanya sering berbenturan dengan hal-hal yang tidak sesuai dengan sikap adil itu sendiri.

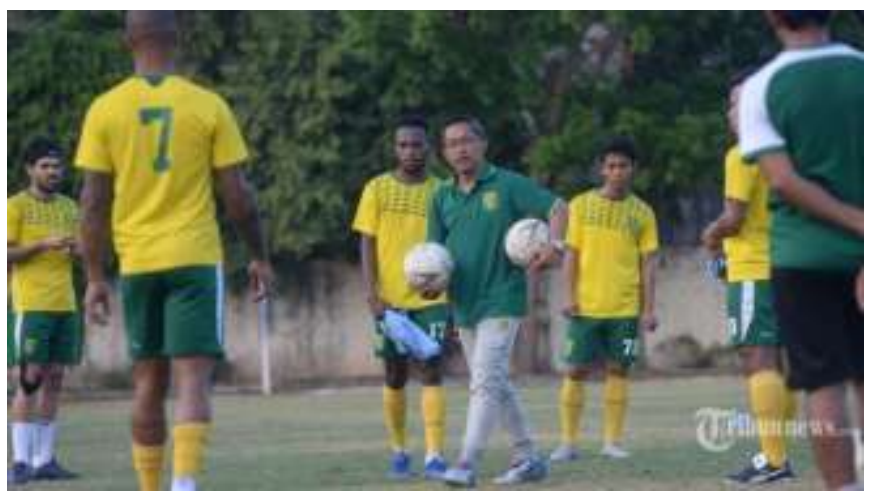

Gambar 9. Coach Aji Santoso Memimpin Latihan [22].

Contoh yang lain dari aktualisasi sila kelima dalam sepak bola ada dalam diri wasit. Seorang pengadil lapangan tentu saja harus bisa bersikap adil. Jangan sampai ada kesan berpihak ke salah satu tim, karena jika seorang wasit terkesan berat sebelah, akan berujung pada keributan. Kriteria menjadi wasit yang baik ada bermacam-macam, diantaranya adalah memiliki sikap adil dan jujur, memiliki pengetahuan sepak bola yang baik, sehat jasmani dan rohani, memiliki lisensi wasit dan memiliki integritas yang tinggi. Secara sederhana, seorang wasit harus bersih dari upaya atau tindakantindakan yang menyimpang. PSSI akan memberikan apresiasi terhadap keberadaan wasit yang dinilai mampu menjadi pengadil terbaik di lapangan. Seperti sosok Thoriq Munir Alkatiri yang pernah menjadi wasit terbaik di Indonesia tahun 2019.

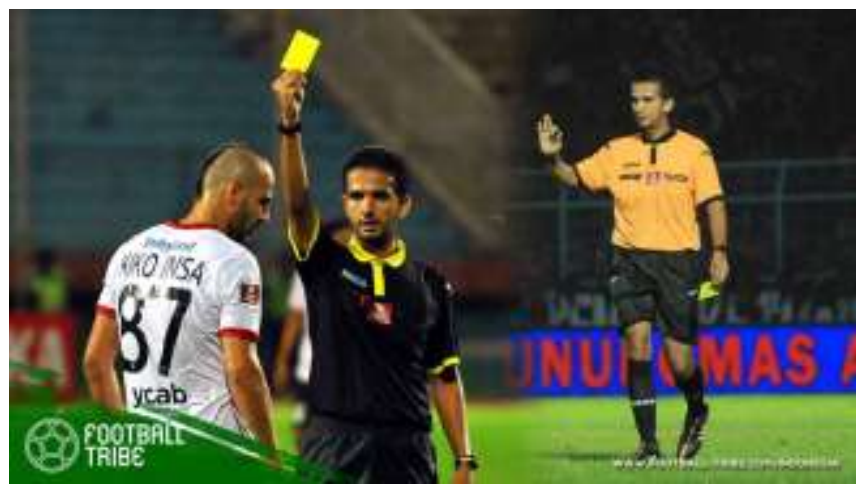


Gambar 10. Keputusan Wasit sebagai Pengadil di Lapangan [23].

Aspek teknik, fisk, taktik dan mental sangat berpengaruh dalam sepak bola dan Pancasila memiliki peran yang besar dalam membangun mental orang yang terlibat di dalamnya. Mentalitas yang positif dapatkan melalui Pancasila dan idealnya dapat diaktualiasasikan dalam situasi sepak bola. Sangat menarik apabila membahas sepak bola melalui sudut pandang Pancasila. Melalui contoh-contoh kasus persepakbolaan yang sering dijumpai, terkadang tidak menyadari bahwa itu merupakan bagian dari Pancasila. Bagian yang dimaksud dapat secara positif, dan bisa pula negatif karena sebuah perbuatan yang terjadi menyimpang dari nilai-nilai Pancasila. Upaya untuk menekankan aktualisasi nilai-nilai Pancasila, idealnya mulai ditanamkan sejak kecil dalam arti sejak masa mereka masih belajar sepak bola di Sekolah Sepak Bola (SSB).

Sepak bola mampu menjadi ikatan persatuan dan kesatuan. Maksudnya, sepak bola tidak sekadar olah raga permainan, tetapi juga olah raga kebangsaan dan kebanggaan. Sila-sila Pancasila diintegrasikan dalam aktivitas sepak bola. Nilai-nilai Ketuhanan, kemanusiaan, kesatuan, kerakyatan, dan keadilan tercermin dari dalam setiap persiapan, latihan, pertandingan, dan aktivitas hidup sehari-hari para pemain.

Melalui olah raga sepak bola yang sekaligus mengaktualisasikan nilai-nilai Pancasila akan menghasilkan sumber daya manusia Indonesia yang baik dan unggul. Sumber daya manusiayang memiliki watak baik. Termasuk dengan mengamalkan nilai-nilai positif yang dijunjung tinggi dalam permaian, pertandingan olah raga maka diharapkan dapat membentuk manusia yang memiliki watak religius, kepemimpinan, disiplin, tanggung jawab, kerjasama, jujur, percaya diri, berani mengambil keputusan, toleransi. Dengan demikian sejalan dengan upaya pembentukan generasi manusia serta kader-kader bangsa yang baik [24]. Sebagaimana halnya upaya penguatan Pancasila dalam menghadapi revolusi industri 4.0 adalah dengan meningkatkan kualitas sumber daya manusia Indonesia yang unggul, yakni yang berjiwa Pancasila [25].

Nilai-nilai yang terkandung dalam olah raga sesungguhnya memiliki dimensi positif sejalan dengan karakter kebangsaan yang sangat bermanfaat untuk memperkokoh keutuhan dan persatuan bangsa. Dalam banyak hal nilai-nilai yang terkandung dalam bidang olah raga secara subtansial memiliki kesejajaran dengan usaha-usaha pengembangan karakter kebangsaan. Ada banyak segi positif yang dapat diambil dan ditranformasikan dalam kehidupan berbangsa dan bernegara. Meskipun terdapat perbedaan tataran teknis antara bidang keolahragaan dan segi kebangsaan, namun tidak dapat dipungkiri bahwa kedua unsur tersebut memiliki kedudukan yang saling menunjang dalam membentuk generasi yang baik dan cerdas. Hal ini diperlukan di tengah kehidupan modern yang berubah dengan cepat, yang ditandai dengan munculnya pergeseran nilai-nilai baru dan arus kehidupan yang makin global yang cenderung meminggirkan identitasidentitas kebangsaan [26]. Implementasian Pancasila dikalangan generasi muda khususnya melalui olah raga sepak bola untuk menambah pemahaman dan membentuk karakter generasi muda yang sesuai dengan Ideologi Pancasila.

\section{SIMPULAN DAN SARAN}

Melalui paparan hasil penelitian dan pembahasan, dapat diketahui bahwa Pancasila dapat mencakup segala aspek kehidupan, salah satunya olah raga sepak bola. Pancasila tidak hanya sekedar terpaku pada kajian politik, ekonomi, budaya, pendidikan namun juga dapat dikaji dan diaktualisasikan dalam sepak bola. Proses aktualisasi nilai-nilai Pancasila dalam sepak bola tanpa disadari sering dijumpai. Demi mewujudkan sikap fair play dan sportif serta mencapai prestasi yang maksimal, tentu saja aspek teknik, fisik, taktik, dan mental harus dapat berjalan secara berkesinambungan. Aspek teknik, fisik, dan taktik jelas dijumpai dari program latihan sepak bola yang sudah direncanakan.

Sedangkan untuk aspek mental tersebut selain didapatkan dari menu latihan sepak bola, didapat dari seberapa jauh memahami tentang aktualisasi nilai-nilai Pancasila dalam sepak bola. Semakin dalam seseorang memahami tentang nilai-nilai pancasila, maka mental bertanding yang profesional akan tumbuh dengan baik. Penyimpangan-penyimpangan seperti perkelahian di dalam lapangan, protes berlebihan, hingga kasus suap dalam pertandingan akan terhindarkan. Secara ideal hal tersebut perlu diajarkan sejak dini saat bergabung dengan sekolah sepak bola. Hal ini dilakukan supaya terbiasa dengan nilai-nilai aktualisasi Pancasila tersebut, maka sikap-sikap positif akan terus terbawa hingga menjadi pemain profesional. Harapannya, tentu nilainilai Pancasila dalam sepak bola tetap diaktualisasikan oleh para pemain, official, perangkat pertandingan, bahkan penonton sekalipun. Dengan demikian, mampu menjadikan olah raga yang menghibur sekaligus memberikan pesan moral melalui keteladanan yang ditampilkan kepada masyarakat luas.

\section{UCAPAN TERIMA KASIH}

Penulis mengucapkan terima kasih kepada Coach Aji Santoso, Evan Dimas Darmono, Septian David Maulana, Awan Setho Raharjo, dan Saddam Emiruddin Gafar yang telah membantu peneliti dengan memberikan deskripsi pengalaman dan aktivitasnya di dalam dunia sepak bola Indonesia, sehingga mampu dijadikan sebagai sumber penelitian ini. Penulis juga menyampaikan ucapan terima kasih kepada pengelola beserta tim reviewer 
Jurnal CIVICUS Universitas Muhammadiyah Mataram yang telah memberikan kesempatan menerbitkan tulisan ini. Semoga tulisan ini mampu memberikan manfaat.

\section{DAFTAR RUJUKAN}

[1] Octavian, "Urgensi Memahami dan Mengimplementasikan Nilai-Nilai Pancasila dalam Kehidupan Sehari-Hari Sebagai Sebuah Bangsa," Bhinneka Tunggal Ika, vol. 5, no. 2, pp. 123-128, 2018.

[2] M. Uzair, "Bangun Ideologi Pancasila Lewat Olah raga.” http://koran-sindo.com/page/news/ 2016-0418/5/67/Bangun_Ideologi_Pancasila__Lewat_Olah raga. (accessed Mar. 03, 2020).

[3] A. Qoriah, "Nasionalisme Olah raga," Media Ilmu Keolah ragaan Indones., vol. 5, no. 2, pp. 1-7, 2015, doi: 10.15294/miki.v5i2.7877.

[4] Aji R, "Sepak Bola dan Eksistensi Bangsa Dalam Olimpiade Masa Orde Lama (1945-1966)," Mozaik Hum., vol. 16, no. 1, pp. 92-103, 2016.

[5] Maliki O, "Kepemimpinan Dalam Olah Raga Membangun Karakter Bangsa (Sebuah Perspektif Pembangunan Kewarganegaraan)," Ilm. Civ., vol. V, no. 2, pp. 855-864, 2015.

[6] J. S. Anggito, Albi, Metodologi Penelitian Kualitatif. Sukabumi. Jawa Barat: CV. Jejak, 2018.

[7] W. Surjaweni, Metode Penelitan. Bantul Yogyakarta: PT. Pustaka Baru.

[8] Raco J.R, Metode Penelitian Kualitatif; Jenis, Karakteristik, dan Keunggulannya. Jakarta: Grasindo, 2010.

[9] Rusli Lutan, Olah raga dan Etika Fair Play. Direktorat Pemberdayaan Ilmu Pengembangan Ilmu Pengetahuan dan Teknologi Olah raga. Jakarta: Direktorat Jendral Olah raga Departemen. Pendidikan Nasional, 2003.

[10] A. Ateng, Asas dan Landasan Pendidikan Jasmani. Jakarta: Departemen Pendidikan dan Kebudayaan Direktorat Jendral Pendidikan Tinggi Proyek Bembinaan Tenaga Kependidikan. Jakarta, 1992.

[11] A. Pribadi, "Fair Play," in Makalah yang disajikan dalam Seminar Nasional Sport Enterpreuneur, 2010.

[12] Pimpinan MPR dan Tim Kerja Sosialisasi MPR, Empat Pilar Kehidupan Berbangsa dan Bernegara. MPR RI, 2012.

[13] "No Title," bbc.com. https://www.bbc.com/ indonesia/trensosial-40203528 (accessed Mar. 03, 2020).

[14] "Timnas Sholat Maghrib Berjemaah di Ruang Ganti Stadion.” https://www.dream.co.id/news/timnassholat-maghrib-berjemaah-di-ruang-ganti-stadion1612171.html (accessed Mar. 03, 2020).

[15] "SKJ 27 Dirikan Panti Asuhan Bonek 1." https://www.persebaya.id/r/910/skj-27-dirikan-pantiasuhan-bonek-1 (accessed Mar. 03, 2020).

[16] "Indra Sjafri Lelang Jaket Timnas Miliknya untuk Membantu Tenaga 2020. http://m.top.skor.id/detail/121187/Indra-SjafriLelang-Jaket-Timnas-Miliknya-untuk-MembantuTenaga-Medis (diakses pada 3 Maret 2020) (accessed Mar. 03, 2020).

[17] Hanafi, "Hakekat Nilai Persatuan dalam Konteks Indonesia (Sebuah Tinjauan Kontekstual Positif Sila Ketiga Pancasila)," Jurnal Ilmu Pendidikan Pancasila dan Kewarganegaraan, vol. 3, no. 1, pp. 56-62, 2018.

[18] "Timnas Indonesia Punya Pelatih Baru di Januari 2020.” https://bolalob.com/read/131520/timnasindonesia-punya-pelatih-baru-di-januari-2020 (diakses pada 3 Maret 2020) (accessed Mar. 03, 2020).

[19] "Hasil Kongres Biasa PSSI di Bali, Iwan Bule Restui Kick Off Liga 1 Musim Ini." https://www.tribunnews.com/superskor/2020/01/25/ hasil-kongres-biasa-pssi-di-bali-iwan-bule-restui-kickoff-liga-1-musim-ini-pada-29-februari-2020 (accessed Mar. 03, 2020).

[20] PSSI, "No Title," twitter. https://twitter.com/pssi/status/108542565371168358 5 (accessed Mar. 03, 2020).

[21] "Gelar Rakor Dengan Kepolisian PSSI Ingin Cocokkam Jadwal Liga 1 2020,” bola.ent, 2020. https://www.bola.net/indonesia/gelar-rakor-dengankepolisian-pssi-ingin-cocokkan-jadwal-liga-1-20203c2feg.html (accessed Mar. 03, 2020).

[22] "Aji Santoso Jadi PElatih Persebaya Surabaya Tularkan Spirit Juara 1997," 2019. https://m.tribunnews.com/superskor/2019/10/31/ajisantoso-jadi-pelatih-persebaya-surabaya-tularkanspirit-juara-1997?page $=2$ (accessed Mar. 03, 2020).

[23] "Thoriq Alkatiri Wakil Indonesia," 2018. https://football-

tribe.com/indonesia/2018/02/13/thoriq-alkatiri-

wakil-indonesia/ (diakses pada 3 Maret 2020). (accessed Mar. 03, 2020).

[24] Olah raga Membangun Karakter Sumber Daya Manusia, "Guntur," in Naskah Publikasi, Yogyakarta: Fakultas Ilmu Keolah ragaan Universitas Negeri Yogyakarta, 2020.

[25] N. Fadilah, "Tantangan dan Penguatan Ideologi Pancasila dalam Menghadapi Era Revolusi Industri 4.0.," J. Digit. Educ. Commun. Arts, vol. 2, no. 2, pp. 66-78, 2019.

[26] U.H. Zhannisa, "Implementasi Nilai-Nilai Olah Raga dalam Pembangunan Nilai Kewarganegaraan dan Memperkokoh NKRI," Ilm. Civ., vol. V, no. 2, pp. 865878, 2015 . 